\title{
種々の添加物を含む溶融砌砂浴に浸漬された鋼に 形成される拡散層
}

\author{
新井 透* 水谷正義* 小松 登*
}

Tohru Arai, Masayoshi Mizutani and Noboru Komatsu : Diffusion Layers of Steel Surfaces Immersed in Fused Borax Baths Containing Various Kinds of Additives.

To investigate the surface layers of steels immersed in various kinds of borax baths, steels were kept in the borax bath containing powders of pure metals, alloys, carbides, oxides and nitrides of such elements as $\mathrm{Ca}, \mathrm{Si}, \mathrm{Al}, \mathrm{Mn}, \mathrm{R}$ are earth, $\mathrm{Mg}, \mathrm{Zr}, \mathrm{Ti}, \mathrm{V}, \mathrm{Nb}, \mathrm{Cr}, \mathrm{Zn}, \mathrm{Co}, \mathrm{Ni}$ and $\mathrm{Cu}$, and their surfaces and cross sections were examined by microscopy, X-ray diffraction and electron probe microanalyses.

The results obtained are summarized as follows.

(1) Iron boride layers were formed on $0.1 \% \mathrm{C}$ steel specimens treated in the bath containing pure metal powders of $\mathrm{Ca}, \mathrm{Si}, \mathrm{Al}$, rare earth, $\mathrm{Mg}, \mathrm{Zr}$ or alloys powders.

(2) In the bath containing a large amount of $\mathrm{Fe}-\mathrm{Ti}$ or Fe-Mn powders, Ti or Mn carbide layers were formed on high $\mathrm{C}$ steel specimens, while iron boride layers were formed on low $\mathrm{C}$ steel specimens.

(3) In the bath containing $\mathrm{Fe}-\mathrm{V}$ or $\mathrm{Fe}-\mathrm{Nb}$ powders, $\mathrm{V}$ or $\mathrm{Nb}$ carbide layers were formed on $0.1 \% \mathrm{C}$ steel specimens.

(4) In the bath containing $\mathrm{Fe}-\mathrm{Cr}$ powders, double layers of $\mathrm{Cr}$ carbide (outer) and $\mathrm{Fe}-\mathrm{Cr}$ solid solutions (inner) were formed on $0.1 \% \mathrm{C}$ steel specimens.

It may be concluded from the results that the tendency to form boride layers is greater in a fused borax bath containing metal powder with a higher free energy change $(-\Delta G)$ of the oxide formation than that of boron oxidation.

(Received August 2, 1974)

\section{I. 緒 言}

溶融硼砂浴に上る浸明処理においては $\mathrm{B}_{4} \mathrm{C}$ 粉末 $\mathrm{Fe}-\mathrm{B}$ 粉末が添加された嗍砂浴がよく用いられるが，吉岡らは $\mathrm{SiC}$ 粉末が添加された嗍矽浴においても $\mathrm{SiC} に よ っ て \mathrm{~B}_{2} \mathrm{O}_{3}$ が還元され浸研処理が可能であることを報告した(1)，その 後上田らは Al, $\mathrm{Mg}$ ，Ca などが源加されてもこれらによる 還元のために矹化物層が形成されることを示した ${ }^{(2)(3)}$. わ れわれも溶融塩による表面処理における硍砂の有用性に興 昧を持ち種々の検討を行なった結果， $\mathrm{A} 1, \mathrm{Mg}, \mathrm{Ca}$ のほか $\mathrm{Si}, \mathrm{Ti}, \mathrm{Mn}$ など酸化物生成自由エネルギーの大きい元素が

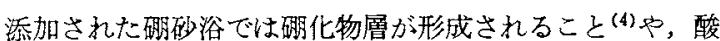
化物生成自由エネルギーの小さい一部の元素が添加された 浴では炭化物層や固溶体層が形成されること坫を報告し た，本報告はその後の研究結果をむ加えて，溶融研砂浴に 添加される物質によって，これに浸漬された鋼表面に形成 される層が異なる機構や，炭化物層の形成の過程を明らか にしようとしたものである。

\section{II. 実 験 方 法}

\section{1. 試 酸 片}

市肘の S 10 C , S 45 C, SK 5, SK 4, SK 3 および SKD 11
を用いた，S10Cは16 $\phi \times 20 \mathrm{~mm}, \mathrm{~S} 45 \mathrm{C}, \mathrm{SK} 5, \mathrm{SK} 4$ ， SK 3 および SKD 11 は $16 \phi \times 5 \mathrm{~mm}$ である。いずれも表 面は $3 \mathrm{~S}$ 以上に仕上げしてある。

\section{2. 拡散処理}

内径 $35 \mathrm{~mm} \phi$ の黒鉛ポットに入れた無水硐砂をポットご 之管状電気炉に入れて $1000^{\circ} \mathrm{C}$ に加熱溶融した後, Table 1 に示した各種の金属，炭化物，窒化物の粉末または小塊を 稂挥しながら少量ずつ添加した。粉末の大きさはすべて 60 メッシュ以下である。添加量は多くの場合 $30 \mathrm{wt} \%$ 一定 とした。この浴の中に脱脂した S $10 \mathrm{C}$ 試片を浸渍して $4 \mathrm{hr}$ 保持後取り出して空冷した。

つぎにポット材質の影響を見るために黒鉛ポットのかわ りK内径 $90 \mathrm{~mm} \phi$ の耐熱鋼(SCH 13) ポッ卜を用いて同様 にして $1000^{\circ} \mathrm{C}$ の無水嗍砂浴を作り，これに Fe-Cr の粉末 を $30 \mathrm{wt} \%$ 添加した。この浴の中に $10 \times 16 \times 20 \mathrm{~mm}$ の大 きさのSK 2 試片を浸清, $8 \mathrm{hr}$ 保持後取り出して空冷した。

また内径 $35 \mathrm{~mm} \phi$ の黑鉛ポットを用いて，同様の要領で $\mathrm{Fe}-\mathrm{Mn}$ 粉末添加量を 5 ～50 wt \% の範囲に夜化させた 1000 ${ }^{\circ} \mathrm{C}$ の無水胡砂浴, Fe-Ti 粉末涯加量を10あるいは $30 \mathrm{wt} \%$ に変化さむた 800,900 および $1000^{\circ} \mathrm{C}$ の無水硼砂浴を作 り，前者には S 10 C, S 45 C, SK 5 , SK 3 および SKD 11,

* 株式会社豊田中央研究所(Toyota Central Research and Development Laboratories, Inc., Nagoya) 
Table 1 Shape and content of additives.

\begin{tabular}{|c|c|c|c|}
\hline Additives & Shape of additives & Chemical composition & Additives content (wt $\%)$ \\
\hline $\begin{array}{l}\mathrm{B}_{4} \mathrm{C} \\
\mathrm{Ca}-\mathrm{Si} \\
\mathrm{Ca}-\mathrm{Al}-\mathrm{Mn} \\
\mathrm{Ca}-\mathrm{Al}-\mathrm{Mn}-\mathrm{Si} \\
\mathrm{La}-\mathrm{Ce} \\
\mathrm{Mg} \\
\mathrm{Fe}-\mathrm{Zr} \\
\mathrm{Al} \\
\mathrm{Fe}-\mathrm{Ti} \\
\mathrm{Fe}-\mathrm{Si} \\
\mathrm{Fe}-\mathrm{V} \\
\mathrm{Fe}-\mathrm{Nb} \\
\mathrm{Fe}-\mathrm{Mn} \\
\mathrm{Fe}-\mathrm{Cr} \\
\mathrm{Zn} \\
\mathrm{Co} \\
\mathrm{Ni} \\
\mathrm{Cu} \\
\mathrm{SiC} \\
\mathrm{TiC} \\
\mathrm{TiN} \\
\mathrm{Si}_{3} \mathrm{~N}_{4} \\
\mathrm{ZrO}_{2} \\
\mathrm{Al}_{2} \mathrm{O}_{3} \\
\mathrm{SiO}_{2}\end{array}$ & $\begin{array}{l}\text { powder } \\
\text { powder } \\
\text { powder } \\
\text { powder } \\
\text { granule } \\
\text { flake } \\
\text { powder } \\
\text { granule } \\
\text { powder } \\
\text { powder } \\
\text { powder } \\
\text { powder } \\
\text { powder } \\
\text { powder } \\
\text { granule } \\
\text { powder } \\
\text { powder } \\
\text { powder } \\
\text { powder } \\
\text { powder } \\
\text { powder } \\
\text { powder } \\
\text { powder } \\
\text { powder } \\
\text { powder }\end{array}$ & $\begin{array}{l}56.8 \% \mathrm{Si}, 35.5 \% \mathrm{Ca} \\
26.6 \% \mathrm{Ca}, 41.7 \% \mathrm{Al}, 29.4 \% \mathrm{Mn} \\
13.3 \% \mathrm{Ca}, 40.2 \% \mathrm{Al}, 30.7 \% \mathrm{Mn}, 14.8 \% \mathrm{Si} \\
56.1 \% \mathrm{Ce}, 35.1 \% \mathrm{La}, 95.0 \% \text { total RE } \\
999.9 \% \\
75 \sim 80 \% \mathrm{Zr}+\mathrm{Hf} \\
99.8 \% \mathrm{Al} \\
40 \sim 45 \% \mathrm{Ti} \\
43.8 \% \mathrm{Si} \\
52 \% \mathrm{~V} \\
59 \% \mathrm{Nb}, 3.6 \% \mathrm{Ta} \\
75 \sim 80 \% \mathrm{Mn} \\
67 \% \mathrm{Cr} \\
99.99 \% \mathrm{Zn} \\
399 \% \\
399 \% \\
>99 \% \\
= \\
= \\
= \\
= \\
=\end{array}$ & $\begin{array}{l}40 \\
18.4 \\
30 \\
30 \\
30 \\
17.6 \\
30 \\
27.8 \\
30 \\
30 \\
30 \\
30 \\
30 \\
30 \\
29.9 \\
30 \\
30 \\
30 \\
30 \\
30 \\
30 \\
16.8 \\
30 \\
30 \\
30\end{array}$ \\
\hline
\end{tabular}

Table 2 Chemical species of the surface layer formed on $\mathrm{S} 10 \mathrm{C}$ specimen and free energy change $(\Delta G)$ of borax-reducing reactions at $1000^{\circ} \mathrm{C}$.

\begin{tabular}{|c|c|c|c|c|}
\hline Additives & $\begin{array}{l}\text { Layer } \\
\text { thickness }(\mu)^{*}\end{array}$ & $\begin{array}{l}\text { Layer } \\
\text { structure* }\end{array}$ & Formula of $\mathrm{B}_{2} \mathrm{O}_{3}$ reducing reaction & $\Delta G$ \\
\hline $\begin{array}{l}\mathrm{B}_{4} \mathrm{C} \\
\mathrm{Ca}-\mathrm{Si} \\
\mathrm{Ca}-\mathrm{Al}-\mathrm{Mn} \\
\mathrm{Ca}-\mathrm{Al}-\mathrm{Mn}-\mathrm{Si} \\
\mathrm{La}-\mathrm{Ce} \\
\mathrm{Mg} \\
\mathrm{Fe}-\mathrm{Zr} \\
\mathrm{Al} \\
\mathrm{Fe}-\mathrm{Ti} \\
\mathrm{Fe}-\mathrm{Si} \\
\mathrm{Fe}-\mathrm{V} \\
\mathrm{Fe}-\mathrm{Nb} \\
\mathrm{Fe}-\mathrm{Mn} \\
\mathrm{Fe}-\mathrm{Cr} \\
\mathrm{Zn} \\
\mathrm{Co} \\
\mathrm{Ni} \\
\mathrm{Cu} \\
\mathrm{SiC}^{\mathrm{TiC}} \\
\mathrm{TiN} \\
\mathrm{Si}_{3} \mathrm{~N}_{4} \\
\mathrm{ZrO}_{2} \\
\mathrm{Al}_{2} \mathrm{O}_{3} \\
\mathrm{SiO}_{2}\end{array}$ & $\begin{array}{r}400 \\
300 \\
270 \\
300 \\
230 \\
140 \\
170 \\
300 \\
100 \\
270 \\
5 \\
5 \\
160 \\
20 \\
= \\
= \\
= \\
= \\
= \\
= \\
=\end{array}$ & $\begin{array}{l}\mathrm{FeB}+\mathrm{Fe}_{2} \mathrm{~B} \\
\mathrm{FeB}+\mathrm{Fe}_{2} \mathrm{~B} \\
\mathrm{FeB}+\mathrm{Fe}_{2} \mathrm{~B} \\
\mathrm{FeB}+\mathrm{Fe}_{2} \mathrm{~B} \\
\mathrm{Fe} \mathrm{Fe}_{2} \mathrm{~B} \\
\mathrm{FeB}+\mathrm{Fe}_{2} \mathrm{~B} \\
\mathrm{FeB}+\mathrm{Fe}_{2} \mathrm{~B} \\
\mathrm{Fe}_{2} \mathrm{~B} \\
\mathrm{FeB}+\mathrm{Fe}_{2} \mathrm{~B} \\
\mathrm{VC} \\
\mathrm{NbC} \\
\mathrm{Fe}_{2} \mathrm{~B} \\
\mathrm{Fe}-\mathrm{Cr}(\mathrm{s} . \mathrm{s}) \\
= \\
= \\
= \\
= \\
= \\
= \\
=\end{array}$ & $\begin{array}{l}- \\
2 / 3 \mathrm{~B}_{2} \mathrm{O}_{3}+2 \mathrm{Ca}=4 / 3 \mathrm{~B}+2 \mathrm{CaO} \\
2 / 3 \mathrm{~B}_{2} \mathrm{O}_{3}+4 / 3 \mathrm{La}=4 / 3 \mathrm{~B}+2 / 3 \mathrm{La}_{2} \mathrm{O}_{3} \\
2 / 3 \mathrm{~B}_{2} \mathrm{O}_{3}+2 \mathrm{Mg}=4 / 3 \mathrm{~B}+2 \mathrm{MgO} \\
2 / 3 \mathrm{~B}_{2} \mathrm{O}_{3}+\mathrm{Zr}=4 / 3 \mathrm{~B}+\mathrm{ZrO} \\
2 / 3 \mathrm{~B}_{2} \mathrm{O}_{3}+4 / 3 \mathrm{Al}=4 / 3 \mathrm{~B}+2 / 3 \mathrm{Al}_{2} \mathrm{O}_{3} \\
2 / 3 \mathrm{~B}_{2} \mathrm{O}_{3}+2 \mathrm{Ti}=4 / 3 \mathrm{~B}+2 \mathrm{TiO} \\
2 / 3 \mathrm{~B}_{2} \mathrm{O}_{3}+\mathrm{Si}=4 / 3 \mathrm{~B}+\mathrm{SiO}_{2} \\
2 / 3 \mathrm{~B}_{2} \mathrm{O}_{3}+4 / 3 \mathrm{~V}=4 / 3 \mathrm{~B}+2 / 3 \mathrm{~V}_{2} \mathrm{O}_{3} \\
2 / 3 \mathrm{~B}_{2} \mathrm{O}_{3}+2 \mathrm{Nb}=4 / 3 \mathrm{~B}+2 \mathrm{NbO} \\
2 / 3 \mathrm{~B}_{2} \mathrm{O}_{3}+2 \mathrm{Mn}=4 / 3 \mathrm{~B}+2 \mathrm{MnO} \\
2 / 3 \mathrm{~B}_{2} \mathrm{O}_{3}+4 / 3 \mathrm{Cr}=4 / 3 \mathrm{~B}+2 / 3 \mathrm{Cr}_{2} \mathrm{O}_{3} \\
2 / 3 \mathrm{~B}_{2} \mathrm{O}_{3}+2 \mathrm{Zn}=4 / 3 \mathrm{~B}+2 \mathrm{ZnO} \\
2 / 3 \mathrm{~B}_{2} \mathrm{O}_{3}+2 \mathrm{CO}=4 / 3 \mathrm{~B}+2 \mathrm{CoO} \\
2 / 3 \mathrm{~B}_{2} \mathrm{O}_{3}+2 \mathrm{Ni}=4 / 3 \mathrm{~B}+3 \mathrm{NiO} \\
2 / 3 \mathrm{~B}_{2} \mathrm{O}_{3}+4 \mathrm{Cu}=4 / 3 \mathrm{~B}+2 \mathrm{Cu} \mathrm{O}_{2} \mathrm{O} \\
2 / 3 \mathrm{~B}_{2} \mathrm{O}_{3}+2 / 3 \mathrm{SiC}=4 / 3 \mathrm{~B}+2 / 3 \mathrm{SiO}_{2}+2 / 3 \mathrm{CO} \\
2 / 3 \mathrm{~B}_{2} \mathrm{O}_{3}+\mathrm{TiC}=4 / 3 \mathrm{~B}+\mathrm{TiO}+\mathrm{CO} \\
2 / 3 \mathrm{~B}_{2} \mathrm{O}_{3}+2 \mathrm{TiN}=4 / 3 \mathrm{~B}+2 \mathrm{TiO}+\mathrm{N}_{2} \\
2 / 3 \mathrm{~B}_{2} \mathrm{O}_{3}+1 / 3 \mathrm{Si} \mathrm{N}_{4}=4 / 3 \mathrm{~B}+\mathrm{SiO}_{2}+2 / 3 \mathrm{~N}_{2} \\
\quad- \\
\quad-\end{array}$ & $\begin{array}{c}- \\
-88 \\
-80 \\
-66 \\
-50 \\
-49 \\
-36 \\
0 \\
+8 \\
+10 \\
+14 \\
+28 \\
+54 \\
+90 \\
+90 \\
+118 \\
+323 \\
+585 \\
+73 \\
+267 \\
- \\
= \\
-\end{array}$ \\
\hline
\end{tabular}

$* 1000^{\circ} \mathrm{C}, 4 \mathrm{hr}$

後者にはS $10 \mathrm{C}, \mathrm{S} 45 \mathrm{C}$ および SK 3 試片を $4 \mathrm{hr}$ 浸漬後取 り出して空冾した。

さらに粉末を添加する方法にかえて内径 $65 \mathrm{~mm} \phi$ の黑鉊 ポットを用いて無我磁础が加熱溶融された $900^{\circ} \mathrm{C}$ の浴を作 成後,この浴の中央に $20 \phi \times 200 \mathrm{~mm}$ の大きさの $\mathrm{Fe}-\mathrm{Cr}$ のブロック(Fe-Cr 地金を高周波炉で溶解して金型に鋳造 して作った)を浸清し，これを陽極ルルツボを陰極として $1 \mathrm{~A} / \mathrm{cm}^{2}$ の電流密度のもとに $8 \mathrm{hr}$ 電解処理した。 $\mathrm{Fe}-\mathrm{Cr}$
ブロックを取り出して後, 粉末添加浴の場合と同様にして SK 4 試片を $2 \mathrm{hr}$ 浸漬保持後, 取り出して空令した。なお 重量減から計算すると上記の電解処理によって $\mathrm{Fe}-\mathrm{Cr} か ゙$ 浴中に $6.8 \mathrm{wt} \%$ だけ溶込んでいた。

\section{3. 組織調查}

処理後の試片を切断グラインダーで切断後, 樹脂に埋め て断面を研摩し光学顕微鏡で観察した。委たこの断面につ いてX線マイクロアナライザーで線分析した，定量のため 
の標準試㸝としてはV，Nb，Cr，Feのそれぞれ純金属を 用いた。

またCo ※たは Fe 管球を用いて表面からX線回折した。

\section{III. 実 験 結 果}

\section{1．添加物と形成される表面層の関保}

Table 2 は溶融䎁砂浴に添加された金瞩粉末の種類とこ れに浸瀆された $\mathrm{S} 10 \mathrm{C}$ 試片の表面に形成された層の関係を 示した。処理条件は $1000^{\circ} \mathrm{C}, 4 \mathrm{hr}$ である。浸胡处理に用 いられている $\mathrm{B}_{4} \mathrm{C}$ はをとより, $\mathrm{Si}, \mathrm{Al}, \mathrm{Mn}, \mathrm{Ti}, \mathrm{Zr}, \mathrm{Mg}$ ， 希土類元素あるいはこれら相互または鉄との合金の添加さ れた浴では，顕微鏡組織やX線回折，X線マイクロアナラ イザーから明らかと硯化物層と見なされる層が形成された

Fig. 1 扎よび 2 に代表として Mg 添加浴で処理した場合の 結果を示す。これらの浴で得られた嗍化物層の深さは $\mathrm{B}_{4} \mathrm{C}$ の添加された浴の場合に比べて小さく $100 〜 300 \mu$ の範囲 であり，Table 2 に見られるように薄い搠化物層は $\mathrm{Fe}_{2} \mathrm{~B}$ 一層からなっている，現化物層の形犾は添加物の種類には 左右されずほぼ同一である。Fig.1の組織では明化物層と

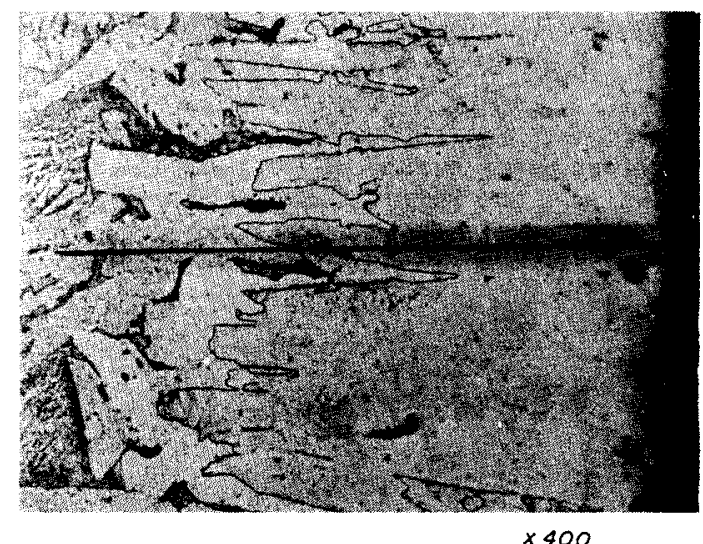

$\times 400$

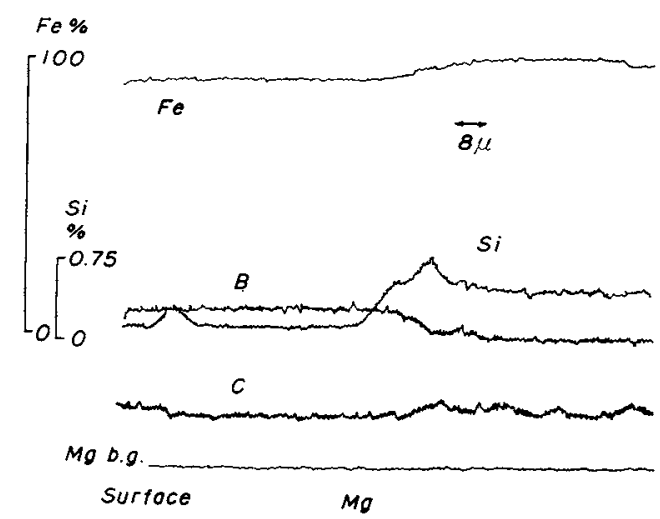

Fig.1 In depth variation of $X$-ray intensity of $C$, $\mathrm{B}, \mathrm{Si}, \mathrm{Mg}$ and $\mathrm{Fe}$ along the line shown in the microstructure of $\mathrm{S} 10 \mathrm{C}$ specimen treated in the fused borax bath containing $\mathrm{Mg}$ powders $\left(1000^{\circ} \mathrm{C}, 4 \mathrm{hr}\right)$.

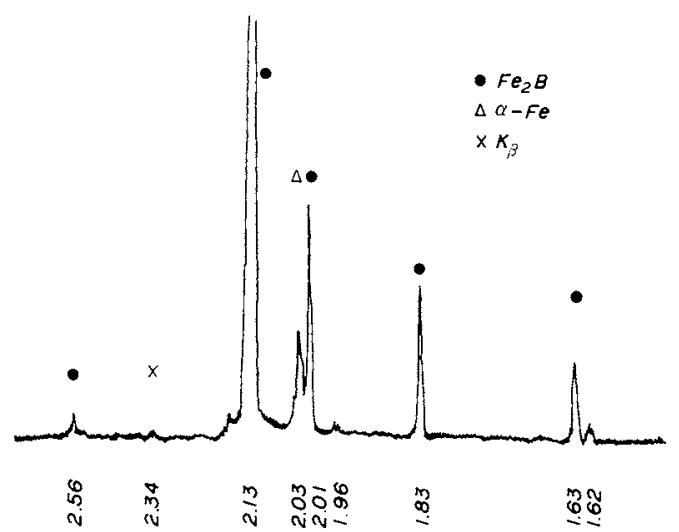

Fig.2 X-ray diffraction pattern of the surface layer of $\mathrm{S} 10 \mathrm{C}$ specimen treated in the fused borax bath containing $\mathrm{Mg}$ powders $\left(1000^{\circ} \mathrm{C}, 4 \mathrm{hr}\right)$.

接した部分が母材とやや異った組織を示しているが，この 部分は $\mathrm{Si}$ が多い，これは表面からの硼化物の形成にとも なって $\mathrm{Fe}$ 硯化物に就ける固溶量の小さい $\mathrm{Si}$ が内部に押 しやられたためであるら ${ }^{(6) \sim(8)}$.

この上うに $\mathrm{Si}, \mathrm{Al}, \mathrm{Ti}, \mathrm{Zr}$ の純金属または合金の粉末が 添加されると醂化物層が形成されたが，これらの元素の酸 化物，炭化物あるいは窒化物が派加された浴では試片表面 には顕徽鏡観察ではとくに変化が認められなかった。これ らの機構について後に考察する。

また $\mathrm{Cu}, \mathrm{Ni}, \mathrm{Co}, \mathrm{Zn}$ の添加された浴によっても試片には 変化が生じなかったが， V, Nb, Cr の鉄合金の添加された 浴で Photo.1 に示寸ように矹化物層とはまったく異っ た層が形成された。 Photo.1(a)はFe-Nb 添加浴によって 形成された谓であって，碵化物層と異なり層は母材とは直 線的な境界を持っている．むた層の厚さは视化物層に比べ てはるが薄く $5 \mu$ である，Fe-V 添加浴で形成された層 は $\mathrm{Fe}-\mathrm{Nb}$ 添加浴で形成されたものと組織，厚さとも同様 であった，Fig.3 は Fe-Nb 添加浴, Fig.4 は Fe-V 添加 浴による層のX線マイクロアナライザー分析の結果であっ て、表面において $\mathrm{Nb}$ またVがCととるに著しく多く存 在している。Bは $\mathrm{Fe}-\mathrm{V}$ 添加浴による層にも Fe-Nb 添加 浴による層にも検出されなかった。また表面にはFe は注 とんど含まれていないが， Fe-V 添加浴による層では Fe 中に少量のVが拡散しているのが琶められる.Fig.5(a)お よび(b)はX線回折の結果であって NbC，VCに相当する 回折線が明確に認められ，これらの層は $\mathrm{NbC}$ あるい性 VC であることが明らかである。Fig. 3 および 4 に扩梳面 のV怙よび Nb の量は $\mathrm{VC}, \mathrm{NbC} の \mathrm{~V}, \mathrm{Nb}$ 量それぞれ 80 , $92 \mathrm{wt} \%$ に比べて小さいが，これは層がうすくて真の値が でていないためであうう。

Photo.1(b)は $\mathrm{Fe}-\mathrm{Cr}$ 添加浴による層の顕微鏡組織であ るが $\mathrm{NbC}, \mathrm{VC}$ 層とは異なり，母材の粒界に優先的に昖散 したような境界をもつ組織となっている，X線マイクロア 
ナライザー分析によるとFig.6のよらに表面のCr 量は 60\% 程度である。委た VC, NbC の湯合に比べて Cr が深 く寻材まで搪散している、Bは㭲出されなかった。Cは表 面で高くなっているがX線回折で湠化物に相当する回折

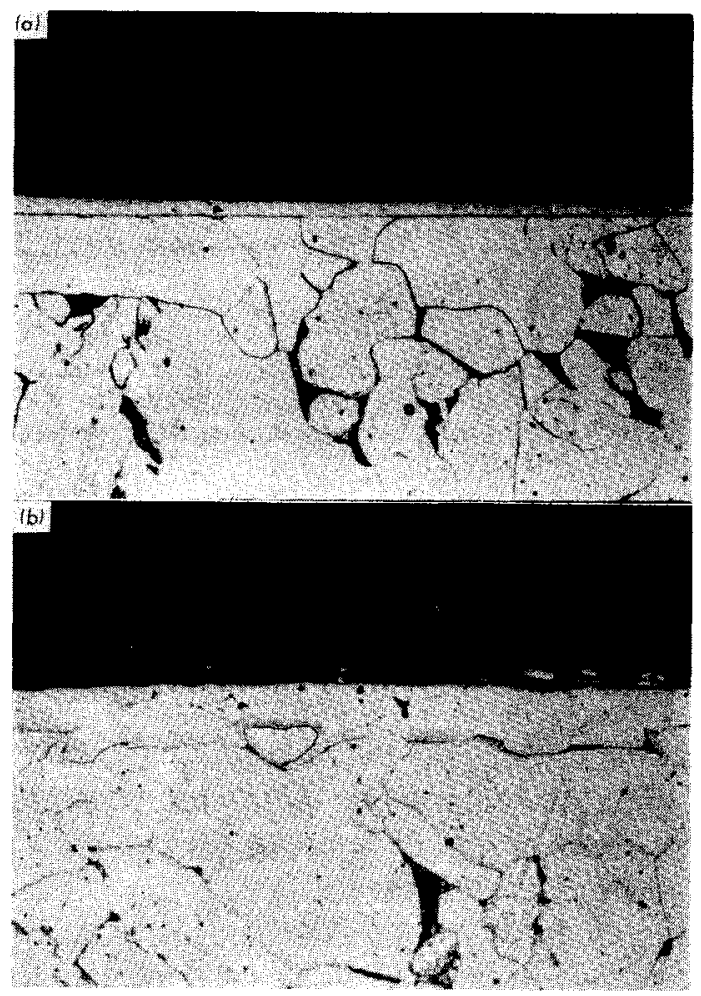

Photo.1 Microstructure of the surface layer of $\mathrm{S} 10 \mathrm{C}$ specimen treated in the fused borax bath containing $\mathrm{Fe}-\mathrm{Nb}$ (a) or $\mathrm{Fe}-\mathrm{Cr}$ powders (b) $\left(1000^{\circ} \mathrm{C}, 4 \mathrm{hr}\right) . \quad(\times 400)$

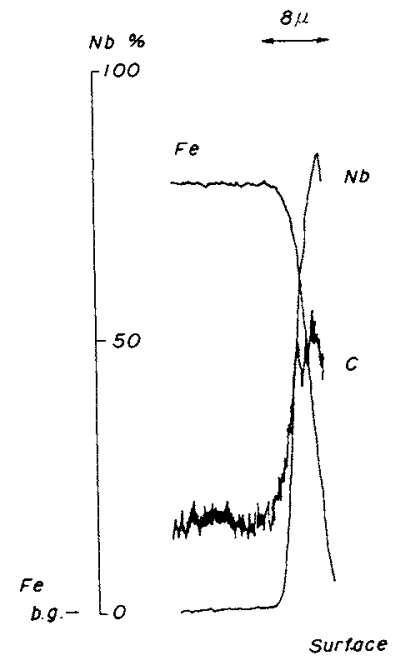

Fig.3 In-depth variation of $\mathrm{X}$-ray intensity of $\mathrm{C}, \mathrm{Nb}$ and $\mathrm{Fe}$ in the surface layer of $\mathrm{S} 10 \mathrm{C}$ specimen treated in the fused borax bath containing $\mathrm{Fe}-\mathrm{Nb}$ powders $\left(1000^{\circ} \mathrm{C}, 4 \mathrm{hr}\right)$.
線はほとんど見られず，Feの回折線が認められるが， $d$ 值

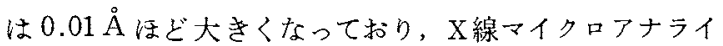
ザーの結果と合せて考劣ればこの層は主として Fe-Cr 固 溶体層であると判断される。な敊つぎに示す上らに母材中 のC量が多くなると，Crの炭化物が明確に娭出されるよ らになることから，この場合にも表面に炭化物がらすく形 成されているであるら。

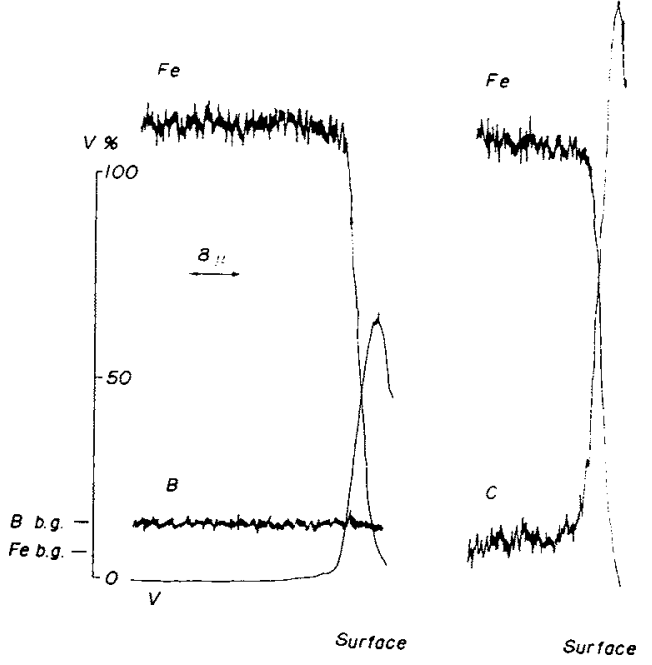

Fig.4 In-depth variation of $\mathrm{X}$-ray intensity of $\mathrm{C}$, $\mathrm{V}, \mathrm{B}$ and $\mathrm{Fe}$ in the surface layer of $\mathrm{S} 10 \mathrm{C}$ specimen treated in the fused borax bath containing $\mathrm{Fe}-\mathrm{V}$ powders $\left(1000^{\circ} \mathrm{C}, 4 \mathrm{hr}\right)$.

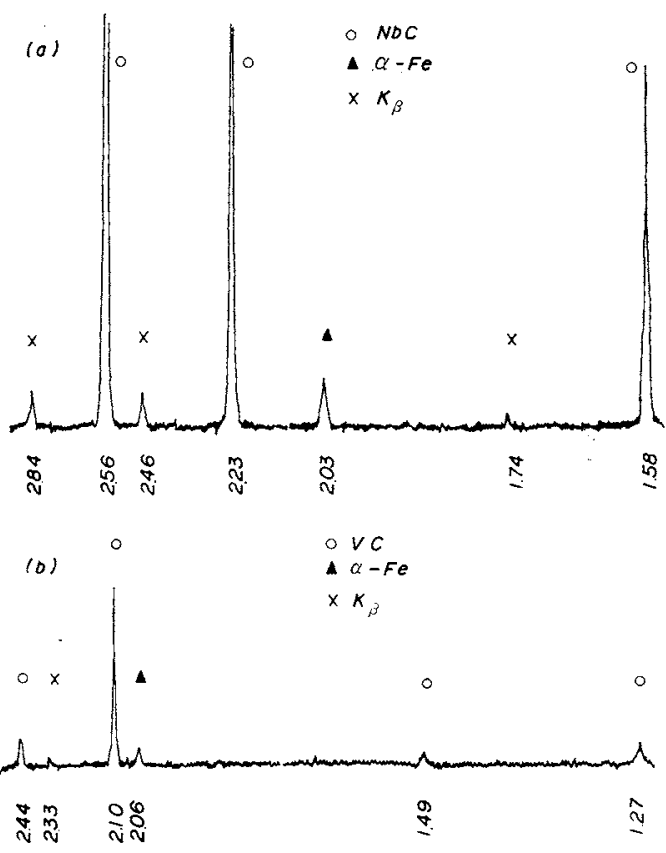

Fig.5 X-ray diffraction pattern of the surface layer of $\mathrm{S} 10 \mathrm{C}$ specimen treated in the fused borax bath containing $\mathrm{Fe}-\mathrm{Nb}$ (a) or $\mathrm{Fe}-\mathrm{V}$ powders (b) $\left(1000^{\circ} \mathrm{C}, 4 \mathrm{hr}\right)$. 


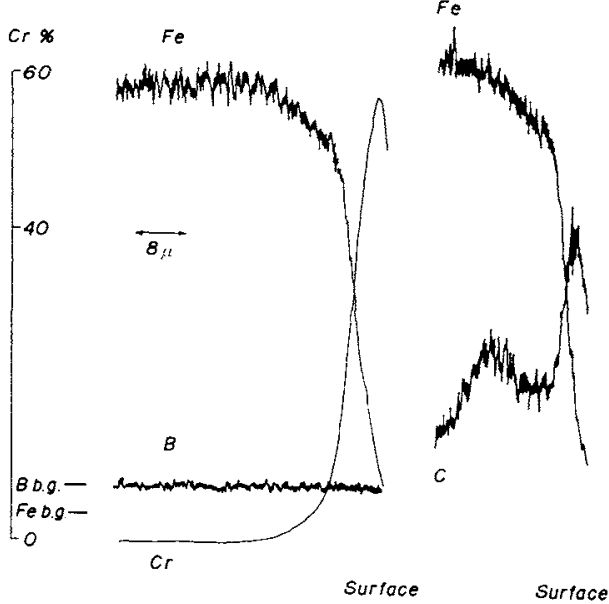

Fig.6 In-depth variation of $\mathrm{X}$-ray intensity of $\mathrm{C}$, $\mathrm{Cr}, \mathrm{B}$ and $\mathrm{Fe}$ in the surface layer of $S 10 \mathrm{C}$ specimen treated in the fused borax bath containing $\mathrm{Fe}-\mathrm{Cr}$ powders $\left(1000^{\circ} \mathrm{C}, 4 \mathrm{hr}\right)$.

これらの結果から添加される物質によって形成される層 が䂹化物，炭化物，固溶体にわかれることが明らかになっ たがこの機構については後に考察する。

\section{2. 耐熱鋼ポットを用いた浴による炭化物層の形成}

黒鉛ポットのか和りに耐熱鎆ポットを用いて SK 2 を $\mathrm{Fe}-\mathrm{Cr} 30 \mathrm{wt} \%$ 添加浴で $1000^{\circ} \mathrm{C}, 8 \mathrm{hr}$ 処理したところ後迹 のPhoto.3 と同様の組織が得られた。Fig.7はをれについ てのX線マイクロアナライザー分析結果, Fig.8 はX線 回折結果である。形成された層は明らかに $\mathrm{M}_{7} \mathrm{C}_{3}$ 拈よび $\mathrm{M}_{23} \mathrm{C}_{6}$ 宸化物であり，Cを含まない容器と浴によっても炭 化物層が形成されることが明らかである。

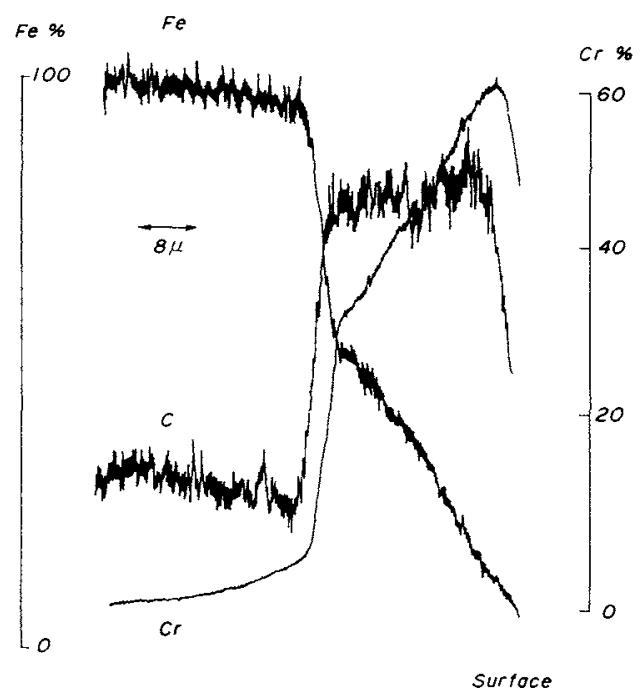

Fig.7 In-depth variation of X-ray intensity of C, $\mathrm{Cr}$ and $\mathrm{Fe}$ in the surface layer of SK 2 specimen treated in the fused borax bath containing $\mathrm{Fe}-\mathrm{Cr}$ powders $\left(1000^{\circ} \mathrm{C}, 8 \mathrm{hr}\right)$.

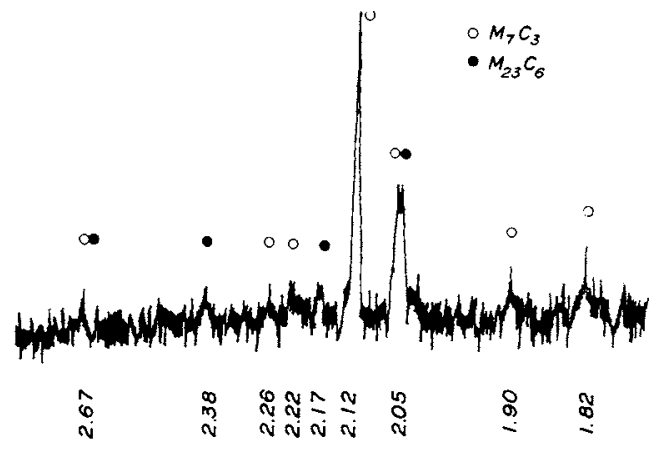

Fig.8 X-ray diffraction pattern of the surface layer of SK 2 specimen treated in the fused borax bath containing $\mathrm{Fe}-\mathrm{Cr}$ powders $\left(1000^{\circ} \mathrm{C}, 8 \mathrm{hr}\right)$.

なお炭化物層の厚さが S $10 \mathrm{C}$ の場合に比べて厚いのは被 処理材中のC量の差によるものである(9).

\section{3. 被処理材のC 量と形成される表面層の関係}

前項の実験では Fe-V, Fe-Nb あるいは Fe-Cr の添加浴 では炭化物層が形成されるにかかわらず，V， Nb， Cr と同 様に炭化物形成元素である $\mathrm{Ti}$ や Mn の鉄合金で伍硼化物 層が形成された，そこで種々の量の Fe-Mn あるいはFeTiが添加された浴に種々のC量をもつ鋼を浸漬して, 添 加量，C量と形成される層の関係を調べた。

Photo.2(a)〜 (c) は Fe-Mn 添加量 30 wt\% あるいは 50 wt \% の浴を用いて SK 3, SKD 11 を $1000^{\circ} \mathrm{C}, 4 \mathrm{hr}$ 処理L た時の組織であって，(a)の Fe-Mn 30\% 浴によるSK 3 お よび(c)の Fe-Mn 50\%による SKD 11 では形成される嬮 は明らかに啲化物層 $\left(\mathrm{Fe}_{2} \mathrm{~B}\right)$ であるが，(b)の Fe-Mn 50\% 浴によるSK 3 に形成されている層は嗰化物層とは異なっ ている.Fig.9のX線マイクロアナライザー分析によれば 表面には Mn が多く，やや内部でBが多くなっている。李 た Fig.10のX線回折によって $\mathrm{Mn}_{5} \mathrm{C}_{2}, \mathrm{M}_{7} \mathrm{C}_{3}, \mathrm{M}_{3} \mathrm{C}$ および $\mathrm{Fe}_{2} \mathrm{~B}$ 飞相当する回折線が検出されるので，この層は表面 部が $\mathrm{Mn}_{5} \mathrm{C}_{2},(\mathrm{Fe}, \mathrm{Mn})_{7} \mathrm{C}_{3},(\mathrm{Fe}, \mathrm{Mn})_{3} \mathrm{C}$ のような炭化物,

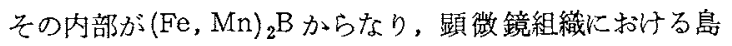
状の組織が後者に相当するであらう。

試片を S $10 \mathrm{C}$, S 45C, SK 5, SK 3, SKD 11, Fe-Mn 添加 量を $5,10,20,30,50$ wt\% と変化させて調べたが，この ような菼化物層が形成されたのは Fe-Mn 50\% 浴で SK 5 ， $\mathrm{SK} 3$ を処理した場合のみで他はすべて典型的な Fe 碸化物 層の組織であった，このことから Fe-Mn 添加量が多くか つ被処理材中のC 量が多い場合にのみ浴中の $\mathrm{Mn}$ が被処理 材中のC と反応して炭化物層を形成し，他の場合は浴中の Bが应散して矹化物層を形成すると判断される。この場合 SKD 11 では炭化物層が形成されないのは被処理材中の全 C量よりは基質のC量に左右されるためでないかと推察さ れる。 Cr その他の炭化物形成元素を多量に含有し，処理 


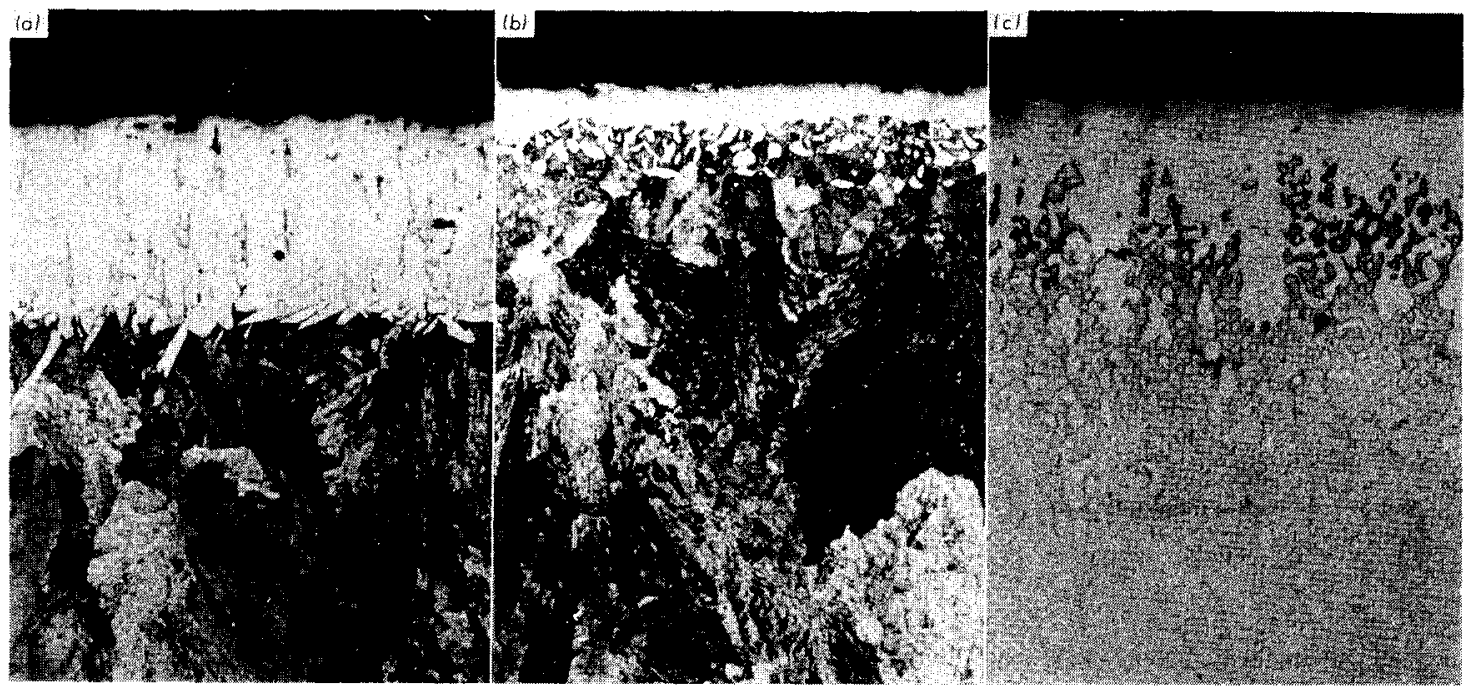

Photo.2 Microstructure of the surface layer of $S K 3^{2}$ or SKD 11 specimen treated in the fused borax bath containing Fe-Mn powders $\left(1000^{\circ} \mathrm{C}, 4 \mathrm{hr}\right) . \quad(\times 400)$

(a) SK $3: 30$ wt $\% \mathrm{Fe}-\mathrm{Mn}$, (b) SK $3: 50$ wt $\% \mathrm{Fe}-\mathrm{Mn}$, (c) SKD $11: 50$ wt $\% \mathrm{Fe}-\mathrm{Mn}$

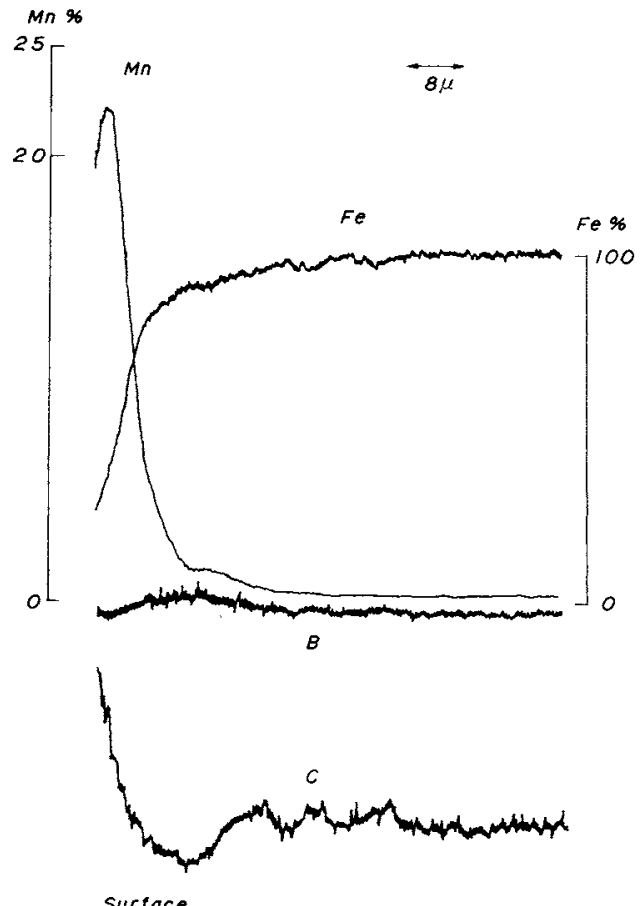

Fig.9 In-depth variation of $\mathrm{X}$-ray intensity of $\mathrm{C}$, $B, M n$ and $F e$ in the surface layer of SK 3 specimen treated in the fused borax bath containing $\mathrm{Fe}-\mathrm{Mn}$ powders $\left(1000^{\circ} \mathrm{C}, 4 \mathrm{hr}\right)$.

温度でも未溶炭化物の多いSKD 11 では基質のC 量は小さ いからである。

Fe-Ti 添加浴において子同様な傾向が認められた。被処 理材, S10C, S 45C, SK 4, SK 3 を Fe-Ti 添加量 10 wt \% または $30 \mathrm{wt} \%$ の浴で $800,900,1000^{\circ} \mathrm{C} て ゙ ~ 4 \mathrm{hr}$ の処理を 施したところ，SK 4 および SK 3 ではFig.11 に示すよう

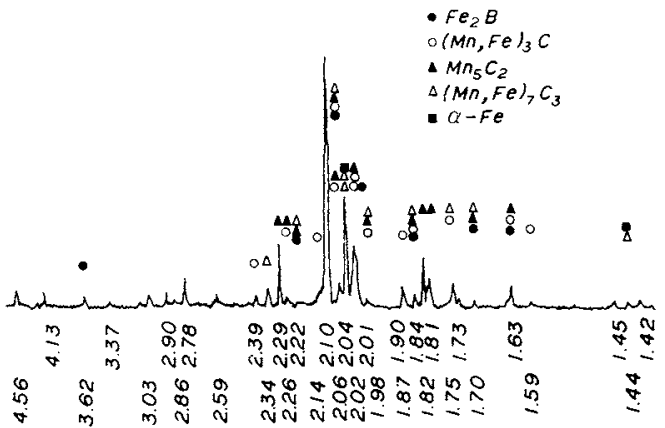

Fig.10 X-ray diffraction pattern of the surface layer of SK 3 specimen treated in the fused borax bath containing Fe-Mn powders $\left(1000^{\circ} \mathrm{C}, 4 \mathrm{hr}\right)$.

な典型的な明化物層とは異なった組織が得られた。Fig.11 は $30 \%$ 添加浴で $1000^{\circ} \mathrm{C}, 4 \mathrm{hr}$ 処理した SK 4 のX線マイ クロアナライザ一分析, Fig.12はX線回折結果である.X 線マイクロアナライザーによる Ti量が TiCにしては低い が、これは層が溥いために正確な值がでていないと考えれ ば，表面には TiC が存在していると判断される．X線回折 では $\mathrm{Fe}_{3} \mathrm{C}$ の回折線が多数見られるが，これは SK 4 に本 来存在する $\mathrm{Fe}_{3} \mathrm{C}$ ではなく， $\mathrm{Ti}$ あるいはBの入った( $\mathrm{Fe}$, Ti) ${ }_{3} \mathrm{C}$ が $\mathrm{Fe}_{3}$ (B, C) である可能性も考えられる. 表面の連続 した層から離れて内部に島状に存在する白い相はFig.11 のBの挙動からも $\mathrm{Fe}_{3}(\mathrm{~B}, \mathrm{C})$ である可能性が高い之考えら れるがこれらについてはもら少し詳細な実験が必要であ る.Fig.11 のような組織はSK 3 の場合 Fe-Ti 添加量, 温 度，時間にかかわらず常に見られたが，S10C では典型的 な湖化物層が形成され，S $45 \mathrm{C} て ゙$ 硼化物層と見られる層 が形成された。なお Fig.11によれ代表面近くにBが存在 


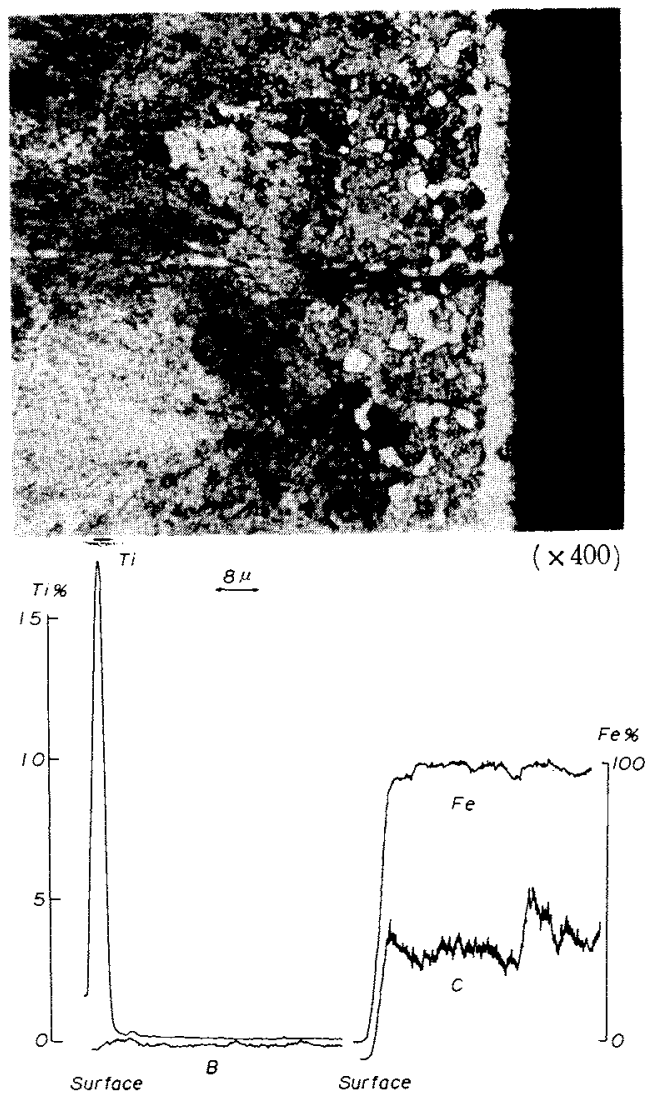

Fig.11 In-depth variation of $\mathrm{X}$-ray intensity of $\mathrm{C}, \mathrm{B}, \mathrm{Ti}$ and Fe along the line shown in the microstructure of SK 4 specimen treated in the fused borax bath containing $\mathrm{Fe}-\mathrm{Ti}$ powders $\left(1000^{\circ} \mathrm{C}, 4 \mathrm{hr}\right)$.

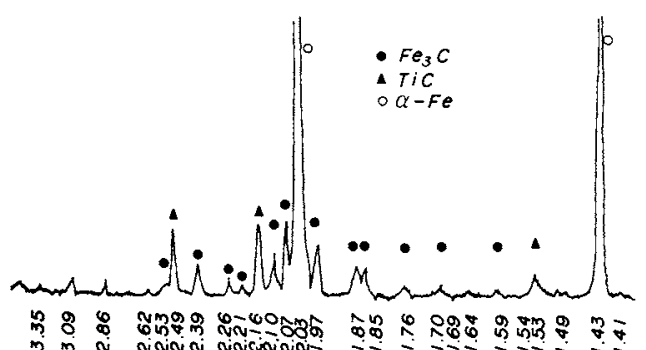

Fig.12 X-ray diffraction pattern of the surface layer of SK 4 specimen treated in the fused borax bath containing Fe-Ti powders $\left(1000^{\circ} \mathrm{C}, 4 \mathrm{hr}\right)$.

するが，これは組織中に和いて表面近くの島状の組織に対 応し，鉄の硼化物または䈐磥化物の可能性がある。

以上の実験結果加ら，Ti p Mn の上らに炭化物形成元 素であると同時に硼砂を罣元する能打をるつ元素が添加さ れた浴では，被処理材のCの多少によって形成される層が 矹化物層末たは炭化物層に分れることが明らかになった。

\section{4. 陽極溶解による $\mathrm{Cr}$ 添加浴による処理}

$\mathrm{Fe}-\mathrm{Cr}$ のブロックを陽極として電解して，Fe 和よび Cr
を溶入させた $900^{\circ} \mathrm{C}$ の矹砂浴で $2 \mathrm{hr}$ 処理した SK 4 の断 面の光学顕微鏡組織をPhoto.3 に示す. $7 \mu$ の厚さの層が 钼察されるがこの層はX 線回折やX線マイクロアナライ ザー分析から $\mathrm{M}_{7} \mathrm{C}_{3}+\mathrm{M}_{23} \mathrm{C}_{6}$ 岑化物層である。

このよ5に陽極溶解によってCが棌加された浴によっ てもCrの抎散層が得られることが確められた。な括この ような現象はV，Nbについても琶められている(9).
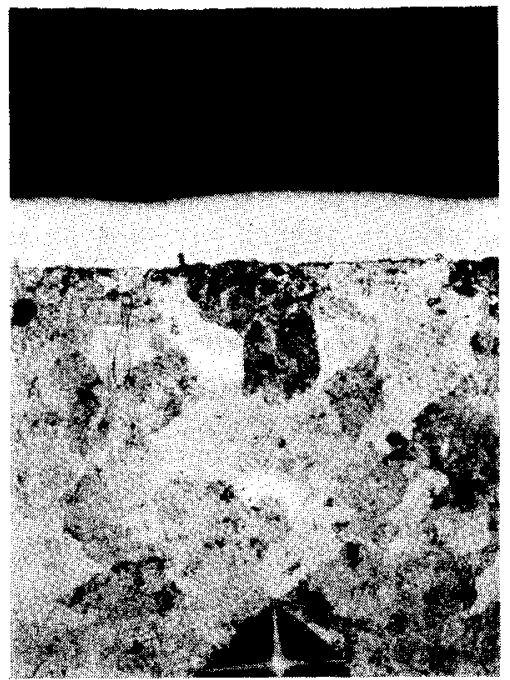

Photo.3 Microstructure of the surface layer of SK 4 specimen treated in the fused borax bath containing $\mathrm{Cr}$, added by anodic resolution $\left(900^{\circ} \mathrm{C}, 2 \mathrm{hr}\right) \cdot(\times 400)$

\section{IV. 考察}

以上の実験結果によれば添加物の種類によって，(1)浸 硼層が形成される，(2)添加物の構成元素の孷化物層また は固溶体層が形成される，(3)層が形成されない，の3 種 類に分かれた。

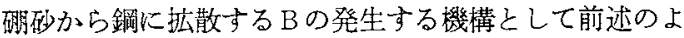
らに吉岡ら (1) 代(1)，(2)のよらな反応を考えている。

$$
\begin{aligned}
& \mathrm{Na}_{2} \mathrm{~B}_{4} \mathrm{O}_{7}+2 \mathrm{SiC} \rightarrow \mathrm{Na}_{2} \mathrm{O} \cdot 2 \mathrm{SiO}_{2}+4 \mathrm{~B}+2 \mathrm{CO} \\
& \mathrm{Na}_{2} \mathrm{~B}_{4} \mathrm{O}_{7}+\mathrm{SiC} \rightarrow \mathrm{Na}_{2} \mathrm{O} \cdot \mathrm{SiO}_{2}+4 \mathrm{~B}+\mathrm{CO}_{2}+\mathrm{O}_{2}
\end{aligned}
$$

また上田ら (2)は磞砂が分解して生じた $\mathrm{B}_{2} \mathrm{O}_{3}$ の $\mathrm{Al}$ ， Ca， $\mathrm{Mg}$ などによる罯元を考えている，Bを含有しない添加物 によって矹化物層が形成されるのであるから，B源として 硯的以外は考光られないのでわれわれも自由エネルギー 変化で整理してみた．Table 3 は添加された各元素の酸化 物，炭化物，窒化物の $1000^{\circ} \mathrm{C}$ に括ける標準生成エネルギー であり，この值を使って矹砂が $\mathrm{B}_{2} \mathrm{O}_{3}$ に解離していて，こ の $\mathrm{B}_{2} \mathrm{O}_{3}$ が還元されると仮定して算出した自由エネルギー 変化 $\Delta G$ をさきの Table 2 に示してある。これによれば 醂化物層が形成された添加物すなわち $\mathrm{La}+\mathrm{Ca}, \mathrm{Mg}, \mathrm{Al}$ ， $\mathrm{Zr}, \mathrm{Ti}, \mathrm{Si}, \mathrm{Mn}$ ではSi, Mn 以外はすべて $\Delta G$ は負であ D，一方炭化物層，固溶体層が形成された添加物では $\Delta G$ 
Table 3 Free energy of formation of various oxides, nitrides and carbides at $1000^{\circ} \mathrm{C}$. (kcal/mol of oxygen, carbon or nitrogen)

\begin{tabular}{l|c|c|c||c|c}
\hline Compounds & $\begin{array}{l}\text { Free energy of } \\
\text { formation }\end{array}$ & Compounds & $\begin{array}{l}\text { Free energy of } \\
\text { formation }\end{array}$ & Compounds & $\begin{array}{l}\text { Free energy of } \\
\text { formation }\end{array}$ \\
\hline $\mathrm{CaO}$ & -242 & $\mathrm{~V}_{2} \mathrm{O}_{3}$ & -146 & $\mathrm{Cu}_{2} \mathrm{O}$ & -36 \\
$\mathrm{La}_{2} \mathrm{O}_{3}, \mathrm{Ce}_{2} \mathrm{O}_{3}$ & -234 & $\mathrm{NbO}$ & -144 & $\mathrm{TiC}$ & -53 \\
$\mathrm{MgO}_{\mathrm{ZrO}}$ & -220 & $\mathrm{MnO}$ & -140 & $\mathrm{SiC}$ & -25 \\
$\mathrm{Al}_{2} \mathrm{O}_{3}$ & -204 & $\mathrm{Cr}_{2} \mathrm{O}_{3}$ & -126 & $\mathrm{TiN}$ & -109 \\
$\mathrm{TiO}_{\mathrm{SiO}}$ & -203 & $\mathrm{ZnO}$ & -100 & $\mathrm{Si}_{3} \mathrm{~N}_{4}$ & -40 \\
& -190 & $\mathrm{CoO}$ & -64 & & \\
\hline
\end{tabular}

はすべて正である。したがって䂤砂からら解離した $\mathrm{B}_{2} \mathrm{O}_{3}$ が 賠元されて解化物層が形成されるとする考え方が妥当であ 万ら. $\mathrm{Al}_{2} \mathrm{O}_{3}, \mathrm{SiO}_{2}, \mathrm{ZrO}_{2}$ のよらな酸化物を添加しても舅化 物層が形成されなかったこともこれを裹付计る事害である 5 .

なお Table 2 の反応式では SiC は $\Delta G$ が正であって眀 化物層は形成されないと考えられるが，実際には SiC 添加 浴によって硼化物層が形成されることが知られており，そ のさいの反応式としては前記式（1）および(2)を考党なけ ればならないのであろう。

$\Delta G$ が正である $\mathrm{V}, \mathrm{Nb}, \mathrm{Cr}$ を含む粉末が添加された浴 で, 被処理材表面にこれらの元素の应散層が形成されたの

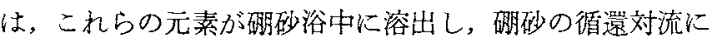
つれて被好理材表面に接触したこれらの元素の原子が被処 理材に拡散して層を形成すると考えられる。矹砂浴中心添 加され浮葹している粉末が被処理材に接触し，粉末中の元 素が直接被処理材に抾散することによって層の大部分が形 成されているとは考えられない。な世゙ならば陽極溶解に よって $\mathrm{Cr}$ や $\mathrm{Nb}, \mathrm{V}$ が添加された浴によってむ粉末添加浴 によるとほとんど同程度の厚さの層が，同一温度，同一漫 漬時間のるとで形成されるからである(10).

このような溶融浴に浸漬することによって㧍散層が形成 される現象としては，これまで Campbell らによる $\mathrm{CrCl}_{2}$ ，

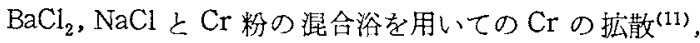
Carter らによるCa を主丳とする溶融浴を用いてのB，Be， $\mathrm{Al}, \mathrm{Si}, \mathrm{V}, \mathrm{Cr}, \mathrm{Co}, \mathrm{Ni}, \mathrm{Cu}, \mathrm{Zn}$ など挫散 ${ }^{(12)(13)}$ ，小菘らに よるA1 を添加した溶融 $\mathrm{Pb}$ 浴を用いてのA1 の拡散 ${ }^{(14)}$, Minkevich らによる $\mathrm{TiO}_{x}$ を添加した溶融 $\mathrm{NaCl}$ 浴による Ti の拡散 ${ }^{(15)}$, Schlechten 5による $\mathrm{TiO}_{x}$ あるいはTiを 添加した $\mathrm{KCl}, \mathrm{NaCl}$ 浴，あるいは Tiを添加した $\mathrm{K}_{2} \mathrm{TiF}_{6}$ と $\mathrm{LiF}, \mathrm{NaF}$ ，あるいは $\mathrm{K}_{2} \mathrm{TiK}_{6}$ と $\mathrm{BaCl}_{2}, \mathrm{NaCl}$ の混合に よる $\mathrm{Ti}$ の㧓散 ${ }^{(16) 〜(18)}$ ，田村らによる $\mathrm{NaPO}_{3}$ を添加した $\mathrm{NaCl}-\mathrm{Na}_{2} \mathrm{CO}_{3}-\mathrm{NaCl}$ 浴によるPの㧓散 ${ }^{(19)}$ などが琶められ ている，この中でCarter らのCa 浴, 小松らの $\mathrm{Pb}$ 浴，お よび Schlechten らによる塩化物の浴の場合にはやはり浴 中心分散した原子が被処理材と衝突することによって搪散 が行われると考光られている。

$\mathrm{Ca}$ 浴の境命にはさらに被処理秒中のC方 Ca と反応し て $\mathrm{CaC}_{2}$ を形成することによって脱Cが行われるなどキャ
リナーとしての Ca との反応が考えられているが，硯砂の

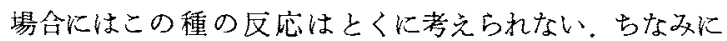
Ca 浴の場合にはC 含毛被処理材の場合にも炭化物層が

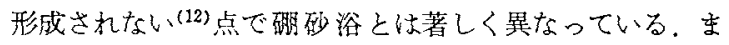
た Schlechten ら, Minkevich らの塩化物浴の場合には形 成された $\mathrm{TiCl}_{2}$ の微小粒が被処理材表面に接触して, $\mathrm{FeCl}_{2}$ を形成しこれによって発生した $\mathrm{Ti}$ が搪散する反応 も考无られているが，硼砂浴ではこの種の置換反応も考箅 の必要はないであるら。

このよらにしてS10Cに形成された被覆層が Fe-V， $\mathrm{Fe}-\mathrm{Nb}$ 添加浴ではVC, NbC であるのに対して, Fe-Cr 添 加浴では被処理材が S10C の場合には大部分が固溶体層で あって孷化物層はごく薄いのであるが，この $\mathrm{V}, \mathrm{Nb}$ と $\mathrm{Cr}$ の挙動の差は炭化物生成自由エネルギーの大小によるので あって強力な炭化物形成元素活ど崖化物を形成しやすいの であるう．CrでもSK 2 やSK 4 を処理した場合に見られ たよらに，被処理材中のC含有量が高ければ $\mathrm{Fe}-\mathrm{Cr}$ 添加 浴であっても $\mathrm{Cr}$ 炭化物層が形成されるのであるが，これ については次報に詳しく報告する予定である。

MnやTi の場合には被処理材中のC 量の多少および添 加量によって形成層が硼化物か炭化物かに分かれたが，こ れは定性的には被処理村表面のC原子，浴の界面付近の $\mathrm{Ti}, \mathrm{Mn}$ 原子が多ければ被処理材表面に和いてCK Ti，Mn が結合して炭化物を形成方るために鉄研化物が形成されな いのであるらと説明できるが，詳細な機構仙不明である。 なお $\Delta G$ が正である V,Nb あるいは $\mathrm{Cr}$ と $\Delta G$ が負であ る元素の双方を添加した浴でも， $\Delta G$ が負である元素の添 加量が小さい場合には炭化物層，多い場合には碽化物層が 形成される現象が琶められているが(9)，これも同じ現象で あら 5 。

$\Delta G$ が正の值を示す元素のなかでも $\mathrm{V}, \mathrm{Nb}, \mathrm{Cr}$ 以外の元 素が添加された浴では本実鉷の場合には層がまったく形成 されなかったが, Carter の Ca 浴の場合にはFeにそれぞ れ最高 $90 \mathrm{wt} \%$ の Co, 最高 $40 \mathrm{wt} \%$ の $\mathrm{Ni}, 1 \mathrm{wt} \%$ 以下の $\mathrm{Cu}$ ，最高 $5 \mathrm{wt} \%$ の $\mathrm{n}$ が含まれた被覆愿が形成されてい る(13)。したがって本実験の場合にもこれらの元素の拡散 は有り得べき現象のよらに思われるが，これが認められな いのは浴の組成の差か処理条件の差であるう。 


\section{V. 結言}

種々の金属, 合金, 炭化物, 酸化物あるいは窒化物の粉

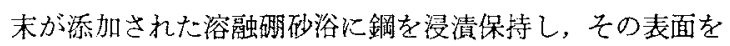
観察した絬果つぎのことが明らかになった。

(1) 嗍砂见 $\mathrm{Si}, \mathrm{Al}, \mathrm{Mn}, \mathrm{Ti}, \mathrm{Zr}, \mathrm{Mg}$, 希土類元素の純金 属, 相互の合金あるい性鉄々の合金の粉末か添加された浴 に鋼が浸漬保持されるとその表面偟鉄の硼化物層が形成さ れる。

（2）ただしMn およびTi の場合には㬄加量が大きく， かつ鋼中のC 含有量が多いとこれらの元素を主成分とする 览化物層が形成される。

(3) V， Nb または Cr の鉄合金の粉末が添加された溶融 硼砂浴济鋼が浸漬されるとこれらの元素を主成分とする炭 化物または固溶体層が形成される。

（4）炭化物層の形成は主として添加された合金粉末から

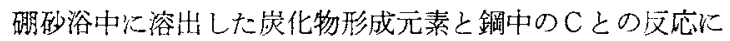
よって行われると考充られる。

(5) 明砂浴に添加される元素の種類によって鋼表面に形 成される層が砳化物層あるいは炭化物層, 固溶体層に別れ る現象は $\mathrm{B}_{2} \mathrm{O}_{3} か ゙$ 添加元素によって置元されると仮定した

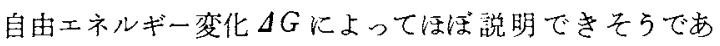
る、 $\Delta G か ゙$ 負である元素が添加された浴では一般に明化物 層が形成され，正である元素が添加された浴では湠化物 層，固溶体層が形成されるか，抬散層が形成されない。

\section{文献}

（1）吉岡正三，山本 久，熊谷雅猜：金属表面技術，21 (1970), 272 .
（2）緗川一夫, 上田益造：金属表面技術協会第 42 回学 術講演大会, (1970).

（3）細川一夫，上田益造，関 文男：金属表面技術，22 (1971) , 442 .

（4）小松 登, 新井透, 水谷正義: 金属学会講演概 要, $(1971 \cdot 10), 235$.

（5）新井 透, 水谷正義, 小松 登: 金属学会講演概 要, $(1972 \cdot 10), 324$.

（6）新井透, 水谷正義，小松 登：金属学会誌，38 (1974) , 949.

(7) H.C.Fiedler and W.J.Hayes : Met. Trans., 1 (1970) , 1071

(8) I.S.Durakarevich and M.A.Balter : Protective Coatings on Metals, Ed. by G.V.Samsonv, Vol.1 $\mathrm{c} / \mathrm{b}$ Consultants Bureau, New York, London, (1969), 30.

(9) 新井 透, 水谷正義, 小松 登: 未発表.

（10）新茾 透，杉本義彦，小松 登: 来発表.

(11) I.E.Campbell, V.D.Barth, R.F.Hoeckelman and B.W.Gonser : J.Electrochemical Soc., 96(1949), 262.

(12) G.F.Carter and R.A.Fleming : J.Less-Common Metals, 14(1968), 167.

(13) G.F.Carter : Metal Prog., 93(1968), 6, 117.

(14) 小松 登, 中村元志, 藤出浩紀：金属表面技術， 23 (1972), 66 .

(15) A.N.Minkevich and A.G.Gvozder : Извест. Вуз уер Металл, (1960), 151.

(16) A.W.Schlechten, M.E.Straumanis and G.B.Gill: J.Electrochem.Soc., $103(1956), 395$.

(17) S.T.Shin,M.E.Straumanis and A.W.Schlechten J.Electrochem. Soc., $104(1957), 17$.

(18) M.E.Straumanis, S.T.Shin and A.W.Schlechten: J.Electrochem. Soc, 104 (1957), 17.

(19)田村今男，山岡幸男，阔田康孝：鉄と鎆，56(1970)， 54 .

\title{
鋼 の 非平衡 加 熱 状 態 図
}

\author{
井口信洋* 横田清義 ${ }^{* *} 三$ 輪敬之***
}

Nobuhiro Iguchi, Kiyoshi Yokota and Yoshiyuki Miwa : On the Non-equilibrium Fe$\mathrm{Fe}_{3} \mathrm{C}$ Phase Diagram in Super-Rapid Heating. In the present study $\alpha+P \rightarrow \gamma$ transformation behavior in the various carbon steels over the range of up to $10^{7 \circ} \mathrm{C} / \mathrm{sec}$ super-rapid heating was investigated in the same method as previously employed for eutectoid steel.

The main results obtained are as follows :

(1) The increments of transformation temperatures from the equilibrium points $\left(A_{c_{1}}, A_{c_{3}}\right)$ in various carbon steels with increasing heating rates (up to $10^{7 \circ} \mathrm{C} / \mathrm{sec}$ ) were determined. $A_{c_{3} \mathrm{f}}$ transformation curves of varioud hypoeutectoid steels are disconteniously jumped in two steps $(0.1 \% \mathrm{C}$ : $150^{\circ} \mathrm{C} / \mathrm{sec}, 0.3 \% \mathrm{C}: 250^{\circ} \mathrm{C} / \mathrm{sec}, 0.5 \% \mathrm{C}: 1000^{\circ} \mathrm{C} / \mathrm{sec}$, and with increasing heating rate, the curve approximated to the $\mathrm{A}_{c 3 \mathrm{f}}$ point of pure iron.

(2) A non-equilibrium phase diagram for less than $1.4 \% \mathrm{C}$ steel was shown. In this diagram

* 早稲田大学理工学部 (Faculty of Science and Engineering, Waseda University, Tokyo)

** 早稲田大学理工学部, 現在: 早稲田大学名誉教授 (Faculty of Science and Engineering, Waseda University Tokyo. Now, Emeritus Professor of Waseda University)

**** 早稲田大学大学院 (Graduate School, Waseda University, Tokyo) 